\title{
Megemlékezés
}

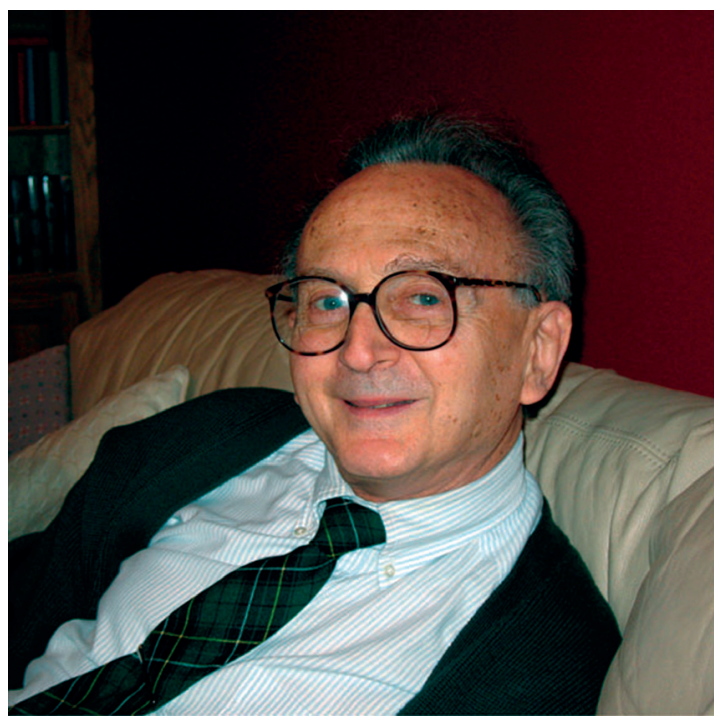

\section{A GENETIKAI KÓD MEGFEJTÉSÉNEK MAGYAR HŐSE: LENGYEL PÉTER (1929-2020)}

\section{THE HUNGARIAN HERO OF THE DECIPHERING OF THE GENETIC CODE: PETER LENGYEL (1929-2020)}

\author{
Venetianer Pál \\ az MTA rendes tagja, emeritus kutató professzor, Szegedi Biológiai Kutatóközpont \\ venetpal@brc.hu
}

\section{ÖSSZEFOGLALÁS}

Ez a megemlékezés Lengyel Péterről, az MTA külső tagjáról szól, aki 2020. április 21-én hunyt el 91 éves korában. Lengyel 1956-ban hagyta el Magyarországot, és a Nobel-díjas Severo Ochoa intézetében dolgozva döntő szerepet játszott a genetikai kód megfejtéséért folytatott tudományos versenyben. Későbbi munkásságában az interferon szerepének kutatásában ért el jelentős eredményeket. 


\section{ABSTRACT}

This obituary commemorates Peter Lengyel, external member of the Hungarian Academy of Sciences who passed away on $21^{\text {st }}$ April 2020 aged 91 . He had left Hungary in 1956, and working in the Institute of the Nobel-prize winner Severo Ochoa, played a decisive role in the scientific competition for the deciphering of the genetic code. In his later research work, he made significant discoveries in connection with the interferons.

Kulcsszavak: polinukleotid-foszforiláz, genetikai kód, messenger-RNS, fehérjeszintézis, interferon

Keywords: polynucleotide-phosphorylase, genetic code, messenger-RNA, protein synthesis, interferon

Néhány éve nálunk is sikerrel játszották a Kódjátszma címü életrajzi filmet a zseniális angol matematikusról, Alan Turingról, aki a német hadvezetés Enigma-kódrendszerének megfejtésével nagyban hozzájárult az angol haditengerészet sikereihez, és ezzel a második világháborúban a szövetségesek győzelméhez.

Nos, az élővilág genetikai kódrendszerének megfejtése a huszadik század hatvanas éveiben ehhez hasonló jelentőségű epizódja volt a tudomány történetének, amely páratlanul izgalmas versenyben dőlt el. E verseny magyar hőse volt Lengyel Péter, a Magyar Tudományos Akadémia külső tagja, a Yale Egyetem nyugalmazott professzora, aki április 21-én hunyt el 91 évesen, woodbridge-i (Connecticut, USA) otthonában.

Lengyel Péter 1929-ben született Budapesten. Eredetileg orvosi pályára készült, de éppen orvos nagyapja beszélte le erről, aki nagyon elégedetlen volt az orvostudomány állásával, és úgy vélte nagyobb szükség volna az azt megalapozó biológiai, biokémiai kutatásokra. Péter tehát a budapesti műszaki egyetemen végzett vegyészmérnökként 1951-ben. Két év katonai szolgálat után kezdett kutatási lehetőség után érdeklődni, és a magyar biokémia „nagy öregjénél”, Straub F. Brunónál jelentkezett aspirantúrára. (A „nagy öreg” ekkor még negyvenéves sem volt. A vele töltött két és fél évről hálás szeretettel és megbecsüléssel ír önéletrajzában.) Az aspirantúrát azonban soha nem fejezte be, mert közben kitört a magyar forradalom, és annak leverése után - mint sok más tehetséges fiatal kutató - Lengyel Péter is elhagyta az országot. Menekülésének irányát kutatói ambíciói határozták meg, erről önéletrajzi vázlatában így ír: „Emlékszem, hogy milyen izgalommal olvastam Budapesten, 1955-ben Grunberg-Manago és Ochoa cikkét arról, hogy a polinukleotid foszforiláz enzim (PNP) RNS-t képes szintetizálni (Grunberg-Manago-Ochoa, 1955). [...] Ez az érdeklödésem a PNP iránt késztetett arra, hogy mindössze egy nappal menekültként New Yorkba érkezésem után megkeressem a felfedezőt, Severo Ochoát. [...] Valószínűleg a magyar ügyért ér- 
zett szimpátiája és az én lelkesedésem bírta rá, hogy elfogadja doktoranduszi jelentkezésemet intézetébe.” (Lengyel, 2014) A spanyol származású Severo Ochoa nagy tekintélyü, elismert biokémikus volt, elsősorban az oxidatív foszforiláció mechanizmusának kutatása területén elért eredményei miatt. A polinukleotid foszforiláz enzim felfedezése (ez vonzotta Lengyelt Ochoához) vezetett két évvel később, 1959-ben Ochoa Nobel-dijához, amelyet Arthur Kornberggel együtt kaptak a ribonukleinsav és a dezoxiribonukleinsav biológiai szintézismechanizmusának felfedezéséért. A tudománytörténet érdekes ténye, hogy noha Ochoa óriási korábbi teljesítménye révén kétségkívül megérdemelte a díjat, a PNP jelentőségének értékelésében mind Ochoa, mind a Nobel-bizottság tévedett, nem ez az enzim felelős a DNS nukleotidsorrendjének lemásolásáért, azaz a genetikai információ továbbításáért. Ennek ellenére fontos eszköznek bizonyult a kód megfejtéséhez.

A genetikai kód fogalmát először minden bizonnyal a Nobel-díjas elméleti fizikus Erwin Schrödinger vetette fel Mi az élet címü könyvében (Szegedi, 2014) arról spekulálva, hogy milyen formában raktározódhat az örökletes információ a génekben. Ez az eleinte elvont kódfogalom akkor kezdett testet ölteni, 1953-ban, amikor James Watson és Francis Crick javaslatot tettek az öröklési anyag, a DNS szerkezetére, és felvetették azt a lehetőséget, hogy a DNS-t alkotó négyféle nukleotid sorrendje hordozza ezt az információt, amely valamilyen kódrendszer szerint meghatározza az aminosavak sorrendjét a fehérjeláncokban (Watson-Crick, 1953).

Crick Nobel-előadásában (Crick, 1962) kizárólag a kódolás problémájával foglalkozott, mert a megelőző kilenc évben számos alapvetően fontos és később igaznak bizonyuló (és néhány téves) hipotézist fogalmazott meg erről a kérdésről. Mi lehet a közvetítő a DNS és a fehérjeszintetizáló apparátus között? Hány nukleotid határoz meg egy aminosavat? Van-e valami jel (vesszö), ami az egyes információs egységeket elválasztja egymástól (mint a szünet a Morse-abc egyes pont-vonás jelcsoportjai között)? Mi szabja meg a folyamatos DNS-óriásmolekulában az egyes fehérjéket kódoló információsor kezdetét és végét? Mindezek a kérdések sokáig kísérletileg még nem voltak megragadhatók. A nagy áttörés egy, a szakmában még elég ismeretlen fiatal kutató, Marshall Nirenberg és német doktorandusza, Heinrich Matthäi nevéhez füződik, akik az USA Nemzeti Egészségügyi Intézeteiben (NIH) dolgoztak. Ők egy ismert, baktériumokból izolált, ép sejtet nem tartalmazó kísérleti rendszert használtak, amely rövid ideig kémcsőben képes volt fehérjét szintetizálni (azaz radioaktívan jelzett aminosavakat beépíteni valami nagyobb molekulába, feltehetően fehérjébe). 1961-ben jelent meg a Nature-ben az a két közlemény, amely bizonyította, hogy a François Jacob és Jacques Monod által megfogalmazott messenger-RNS-koncepció igaz, hogy létezik az az információközvetítő molekula, a rövid életü messenger-RNS, amely a DNS egy szakaszának a másolata, és amely meghatározza az adott szakasz által kódolt fehérje aminosavsorrendjét. Nirenberg és Matthäi tehát, feltételezve, hogy 
a kísérleti rendszerükben a fehérjeszintézist az ott jelen lévő kis mennyiségü és bomlékony messenger-RNS determinálja, szándékosan kimerítették a rendszert (azaz a messenger-RNS lebomlásával megszünt annak szintetizáló képessége), majd hozzáadtak egy mesterségesen előállított, ismert szerkezetü RNS-t, egy monoton, csak U-t (uridilsav, az RNS-t alkotó négy nukleotid egyike) tartalmazó polinukleotidot. És íme, a rendszer működni kezdett, szintetizált egy monoton, csak fenilalanint (a fehérjéket alkotó húsz aminosav egyike) tartalmazó polipeptidet (Nirenberg-Matthäi, 1961). A kísérletet 1961. május 27-én végezték el. Ez az eredmény annyit jelentett, hogy megfejtették a kód-abc első betủjét: a fenilalanint csak U-kból álló jel kódolja. Akkor még csak sejtették, amit annak az évnek a végén Crick és Sydney Brenner bebizonyítottak (Crick et al., 1961), hogy a kód triplet természetü, három nukleotid kódol egy aminosavat, vagyis a fenilalanin kódja UUU. A kísérlethez használt poliU akkor kereskedelemben még nem létezett, laboratóriumi eloállításához PNP-enzimre volt szükség, amivel csak Ochoáék laboratóriuma rendelkezett. A poliU-t személyes kapcsolat révén onnan kapták Nirenbergék. Nem meglepő tehát, hogy Ochoa munkatársának, a PNP-vel foglalkozó Lengyel Péternek, amikor a Cold Spring Harbor Laboratory nyári szimpóziumán meghallotta Brenner előadását a messenger létének bizonyításáról (1961. június 6-án) (Brenner, 1961), szintén az az ötlete támadt, hogy „homopoliribonukleotidokat lehetne kipróbálni messengerként. Ha ezek müködnének, akkor arra késztetnék a riboszómákat, hogy homopolipeptideket szintetizáljanak (például talán a poli-C indukálhatná a polileucin szintézisét)" (Lengyel, 2012). Ötletét elmondta több kollégájának is. Július 31-én egy barátja telefonált a Rockefeller Egyetemről, mondván, hogy szenzációs áttörés történt. Lengyel első szava az volt: „csak azt ne mondd, hogy megfejtették a kódot!” A válasz: „De igen, valaki az MIT-ről [ez tévedés volt, a valóság NIH, V. P.] azt állítja, hogy a poliU polifenilalanint kódol.” A hír óriási csalódás volt Lengyel számára, hiszen azt jelentette, hogy eltervezett kísérleti projektjét valaki más megvalósította. Az információ ekkor még csak pletyka volt, mert Nirenbergék felfedezése csak az amerikai akadémia közleményeinek (Proceedings of the National Academy of Sciences of the United States of America, PNAS) októberi számában került közlésre (bár előadás formájában - óriási szenzációt keltve - már augusztusban elhangzott a moszkvai biokémiai világkongresszuson). Lengyel augusztus elején megírta ötletét a külföldön tartózkodó Ochoának, és elhatározták, hogy mégis belekezdenek a tervezett projektbe, mert van elképzelésük és eszközük arra, hogy nem csak monoton polinukleotidokkal lehet dolgozni. Meghatározott szekvenciájú polinukleotidokat ugyan nem tudtak elóállítani, de a PNP által kémcsőben szintetizált polinukleotidok bruttó összetétele tükrözte a szintézishez felhasznált előanyagok (nukleotidok) mennyiségi arányát. Tehát ha az U aránya a C-hez 5:1 volt, akkor kiszámítható volt, hogy a polinukleotidban a 3U tripletek aránya a 2U1C-hez 5:1 és az 1U2C-hez 25:1. Mivel a tényleges kísérletben a beépült fenila- 
lanin és szerin aránya megközelítette az 5:1-et, arra következtettek, hogy a szerint 2U1C összetételü triplet kódolja. Ilyen típusú kísérletek alapján az Ochoa-csoport első közleménye a PNAS decemberi számában jelent meg Lengyel első szerzőségével (két hónappal Nirenbergék után) (Lengyel et al., 1961), amelyben már több kódtriplet összetételét közölték.

Ennek a cikknek nem volt egyértelmüen kedvező visszhangja a tudományos közvéleményben. Sokan gondolták úgy, hogy a magányos ifjú zseni versenytársaként egy Nobel-díjas vezető kutató hatalmas erőforrásaival vetélkedni nem sportszerủ dolog. Lengyel visszaemlékezésében idézi Robert G. Martint, Nirenberg munkatársát. „Mi az NIH-ben rettentő dühösek voltunk Ochoára és kollégáira, hogy így ráugrottak Marshall (Nirenberg) és Heinrich (Matthäi) felfedezésére. Persze tény, hogy ők is a fehérjeszintézis témáján dolgoztak addig is. Lengyel Péter, az Ochoa-csapat vezető kutatója azt állítja, hogy ők eltervezték ezeket a kísérleteket, mielőtt hallottak volna Marshall eredményeiröl. Biztos vagyok benne, hogy igazat mond." (Lengyel, 2012) Nos, Lengyel Péter igazsága dokumentálható az Ochoának írt augusztusi levéllel.

Ekkor már nyilvánvaló volt a tudományos közvélemény számára, hogy két laboratórium versenyez a kód megfejtéséért. Rollin Hotchkiss a Rockefeller Egyetem kiváló tudósa (mellesleg a magyar biológusok nagy barátja, a Szegedi Biológiai Központ tanácsadója az alapítás utáni időszakban) szerint: „Az U2-incidens indította el a hidegháborút, az U3-incidens a kódháborút" [A magyar fordítás nem adja vissza a szójátékot: 'cold war' és 'code war'. A mai olvasó talán azt sem tudja, hogy az amerikai U2 felderítő repülőgép lelövése a szovjetek által, új fejezetet indított el a hidegháborúban. V. P.] (Lengyel, 2012). Ebben a kódháborúban 1961 végén Lengyel Péterék álltak nyerésre. Karácsonykor a The New York Times már arról tudósított, hogy Ochoa és csapata megfejtette a kódot. Ez a hír mindenképpen korai volt még, de tény, hogy ekkor és a következő év során a húsz aminosav közül tizennyolcra vonatkozóan már megismerték a kódtripletek bruttó összetételét, bár a tripleten belüli sorrendet nem (a módszer nem tudott különbséget tenni a CAA-, ACA- és AAC-tripletek között). A célszalagot azonban végül mégis Nirenberg szakította át, aki egy teljesen más módszerrel, doktorandusza, Philip Leder (aki szintén az idén, februárban hunyt el) segítségével mind a hatvannégy lehetséges kódtriplet valószínü jelentését meghatározta 1964-ben (Nirenberg-Leder, 1964). A biológiai tudomány történetének eme izgalmas és dicsőséges fejezetére a koronát az indiai-amerikai Har Gobind Khorana tette fel, aki ismert nukleotidsorrendủ szintetikus DNS-molekulák segítségével pozitívan bizonyította annak a genetikai kódnak az igaz voltát, amely az általa véglegesített formában ma minden elemi biológia tankönyvben olvasható (Khorana, 1968). Így a Nobel-díjat 1968-ban Nirenberg, Khorana és Robert William Holley nyerték el „a genetikai kód megfejtéséért és a fehérjeszintézisben játszott szerepének tisztázásáért". (Holley némileg kakukktojás ebben a trióban, mert ugyan megérde- 
melte a díjat az első szállító-RNS molekula szerkezetének meghatározásáért, de munkája csak közvetetten kapcsolódott a kód megfejtéséhez.)

Lengyel Péter 1962-ben megírta és sikerrel védte meg a Szintetikus polinukleotidok felhasználása a genetikai kód megfejtéséhez címú doktori disszertációját. Ezután egy évet töltött egy másik későbbi Nobel-díjasnál, Jacques Monod-nál a párizsi Pasteur Intézetben. Az USA-ba visszatérve még egy évig maradt a New York Egyetemen (NYU), majd 1965-ben elfoglalta első végleges állását a Yale Egyetemen, onnan ment nyugdíjba csaknem egy fél évszázaddal később.

Természetesen az évtizedek során még számos fontos felfedezést tettek Lengyel és munkatársai, ezek felsorolására itt nincs mód. Néhány évig a fehérjeszintézis biokémiai mechanizmusával foglalkozott, e munkássága elismeréseként ő foglalta össze a fehérjeszintézissel foglalkozó nagy Cold Spring Harbor Szimpózium tanulságait 1969-ben (Lengyel, 1969). A hetvenes évektől kutatásai középpontjába az interferon került. Ö és csoportja állítottak elő először háromféle interferont tisztán. Charles Weissmannal együttműködve klónozták az első interferon géneket. Sokat foglalkoztak az interferon hatásmechanizmusával, felfedezték és jellemezték az úgynevezett p200-géncsoportot, elsősorban a p204-géneket mint a sejtosztódás és differenciáció többfunkciós szabályozóit.

A tudományos versenyek annyiban hasonlítanak a sporthoz, hogy a szélesebb közvélemény és az utókor emlékezete megőrzi az aranyérmes, a győztes nevét és teljesítményének értékét, de a tőle csak századmásodpercekkel elmaradó ezüstérmesét elfelejti. Lengyel Péter és munkatársainak gyönyörü kísérleti eredményei egy-két hónappal maradtak le a Nobel-díjas győztesétől. Nekünk, magyar kutatóknak azonban megtisztelö kötelességünk, hogy méltóképpen megemlékezzünk erről a nagy tudósról, akadémikus társunkról, akiről a Yale Egyetem nekrológja azt írta: „Híres volt a Yale-en kivételes memóriájáról, hatalmas tudásáról a tudomány és a kultúra minden területén, valamint hihetetlenül gondosan elökészített, precíz és folyékony előadásairól, amelyekhez sohasem használt jegyzeteket, csak krétával és a táblával közvetítette a legbonyolultabb tárgyakat is." Egy régi tanítványa szerint: „Egyike volt a legnagyobb tudású biokémikusoknak, akit valaha ismertem. És nagyszerü mentor volt.”

\section{IRODALOM}

Brenner S. (1961): RNA, Ribosomes, and Protein Synthesis. Cold Spring Harbor Symposia on Quantitative Biology, 26, 101-110. DOI: 10.1101/sqb.1961.026.01.015

Crick, F. H. C. (1962): Nobel Lecture. On the Genetic Code. https://www.nobelprize.org/prizes/ medicine/1962/crick/lecture/

Crick, F. H. C. - Bamett, L. - Brenner, S. et al. (1961): General Nature of the Genetic Code for Proteins. Nature, 192, 1227-1232. DOI: 10.1038/1921227a0 
Grunberg-Manago, M. - Ochoa, S. (1955): Enzymatic Synthesis and Breakdown of Polynucleotides: Polynucleotide Phosphorylase. Journal of the American Chemical Society, 77, 3165-3166. DOI: $10.1021 /$ ja01616a093

Khorana, H. G. (1968): Polynucleotide Synthesis and the Genetic Code. Harvey Lectures, 62, 79105. DOI: $10.1101 / \mathrm{sqb} .1966 .031 .01 .010$

Lengyel P. (1969): The Process of Translation as Seen in 1969. Cold Spring Harbor Symp. Quant. Biol., 34, 828-841. DOI: 10.1101/sqb.1969.034.01.094, https://www.researchgate.net/publication/45658404_The_Process_of_Translation_as_Seen_in_1969

Lengyel P. (2012): Memories of a Senior Scientist on Passing the Fiftieth Anniversary of the Beginning of Deciphering the Genetic Code. Annual Review of Microbiology, 66, 27-38.

Lengyel P. (2014): Wanderings in Biochemistry. The Journal of Biological Chemistry, 289, 19254-19268. DOI: 10.1074/jbc.X114.554121, https://www.ncbi.nlm.nih.gov/pmc/articles/ PMC4094036/

Lengyel P. - Speyer, I. P. - Ochoa, S. (1961): Synthetic Polynucleotides and the Amino Acid Code. Proceedings of the National Academy of Sciences of the USA, 47, 1936-1942. DOI: 10.1073/ pnas.47.12.1936, https://www.pnas.org/content/47/12/1936

Nirenberg, M. W. - Leder, P. (1964): RNA Codewords and Protein Synthesis: The Effect of Trinucleotides upon Binding of sRNA to Ribosomes. Science, 145, 1399-1407. DOI: 10.1126/science.145.3639.1399, https://www.ncbi.nlm.nih.gov/pmc/articles/PMC301388/

Nirenberg, M. W. - Matthäi, J. H. (1961): The Dependence of Cell-free Protein Synthesis in E. Coli upon Naturally Occuring Or Synthetic Polyribonucleotides. Proceedings of the National Academy of Sciences of the USA, 47, 1588-1602. DOI: 10.1073/pnas.47.10.1588, https://www. pnas.org/content $/ 47 / 10 / 1588$

Szegedi P. (szerk.) (2014): Erwin Schrödinger válogatott írásai. Budapest: Typotex Kiadó

Watson, J. D. - Crick, F. H. C. (1953): Genetical Implications of the Structure of Deoxyribonucleic Acid. Nature, 171, 964-967. DOI: 10.1001/jama.1993.03500150079031, https://www.exploratorium.edu/origins/coldspring/printit.html 